\title{
Composition of Senegal millets and sorghums
}

\author{
BY J. ADRIAN" \\ Laboratoire de Biochimie de la Nutrition du C.N.R.S., Bellevue, S. et O., France \\ AND C. SAYERSE \\ Laboratoire de l'O.R.A.N.A., Service de Santé, Dakar, A.O.F. \\ (Recetived 4 April 1956-Revised I5 August 1956)
}

\begin{abstract}
French West Africa, like other regions in which the general standard of nutrition is low, is a great consumer of cereals. Wheat flour is imported and the growing of rice is being developed; there is also a large local production of cereals suited to a subtropical climate, amongst which millets and sorghums occupy an important place. In $195^{2}$ the production of millets and sorghums together amounted to over 2.6 million metric tons, more than one-fifth of the total produced in Africa (Food and Agriculture Organization of the United Nations, 1953). These cereals can be grown on poor soil, and the local climate suits thern admirably. They need little water; the millets grow well if they have between I 6 and 30 in. of rainfall a year and the sorghums grow best with about $3^{6}$ in. (Viguier, 1947 ). The dry steppe and savannah types of country are most suitable for them.

The purpose of the present investigation was to study the nutritive value of the millets and sorghums eaten by the local population, and to compare those grown by peasant cultivation with others grown experimentally in order to determine the influence of the method of culture.
\end{abstract}

\section{EXPERIMENTAL.}

Samples. Two series of samples were analysed, eleven cultivated by the peasants and twenty-one grown experimentally. The former were either bought in the African market of Dakar or obtained from regions (Cap Vert and Popenguine) near that town, and the details of their cultivation were unknown. The latter were provided by the Government Agronomic Research Station at Bambey, Senegal. They were selections from the indigenous species (or varieties) cultivated by the peasants and have been cultivated at the Research Station under standardized conditions, which included the distribution of about 5 metric tons of manure to the acre; any differences found in them could therefore be attributed confidently to genetic causes.

Information about the samples is given in Table $\mathrm{I}$. There was a notable difference in the weight of the millet seeds, those from the Agronomic Station being considerably heavier than the others.

Methods of analysis. Total ash was obtained by incineration, total reducing substance after hydrolysis of polysaccharides, fat by extraction with carbon tetrachloride 
and nitrogen by Kjeldahl estimation. Minerals were determined by the methods of the Association of Official Agricultural Chemists (1945). Vitamins were assayed microbiologically: thiamine by the method of Sarett $\&$ Cheldelin (1944), riboflavin by that of Snell \& Strong (1939), nicotinic acid by that of Krehl, Strong \& Elvehjem (1943) and pantothenic acid by that of Pennington, Snell \& Williams (1940). Determinations of amino-acids in the proteins was also done by a microbiological method developed by one of us (J.A.) (Adrian, 1955).

Table I. Information about the samples analysed

\begin{tabular}{|c|c|c|c|c|}
\hline $\begin{array}{l}\text { Method of } \\
\text { cultivation }\end{array}$ & Variety & $\begin{array}{l}\text { No. of } \\
\text { samples }\end{array}$ & $\begin{array}{l}\text { Mean } \\
\text { weight of } \\
\text { I000 seeds* } \\
\text { (g) }\end{array}$ & $\begin{array}{c}\text { Specific } \\
\text { gravity }\end{array}$ \\
\hline Peasant & $\begin{array}{l}\text { Souna (early) } \\
\text { Sanio (late) }\end{array}$ & $\left.\begin{array}{l}3 \\
4\end{array}\right\}$ & $6 \cdot 5$ & $0.8 \mathrm{I}$ \\
\hline Experimental & $\begin{array}{l}\text { Pennisetum pycnostachyum } \\
P . \text { nigritarum } \\
P . \text { pycnostachyum } \times \text { nigritarum }\end{array}$ & $\left.\begin{array}{l}4 \\
2 \\
2\end{array}\right\}$ & $8 \cdot 2$ & 0.82 \\
\hline \multicolumn{5}{|c|}{ Sorghums } \\
\hline Peasant & Bassi & 4 & $28 \cdot 1$ & 0.77 \\
\hline Experimental & $\begin{array}{l}\text { Sorghum guineensis } \\
\text { S. durra } \\
\text { S. caffra }\end{array}$ & $\left.\begin{array}{l}8 \\
3 \\
2\end{array}\right\}$ & $29 \cdot 0$ & 0.74 \\
\hline
\end{tabular}

* In all the seeds about $60 \%$ of the weight was accounted for by the kernel and about $40 \%$ by the husk.

\section{RESULTS}

The results of the analyses are given in Tables $2-4$.

\section{Table 2. Composition of the millets}

(All values are for $100 \mathrm{~g}$ fresh material)

Moisture (g)

Component

Ash (g)

Total reducing substances $(\mathrm{g})$

Fat (g)

Protein $(\mathrm{N} \times 5.83)(\mathrm{g})$

Calcium (mg)

Phosphorus (mg)

Ratio, Ca: $\mathrm{P}$

Potassium (mg)

Sodium (mg)

Ratio, K:Na

Thiamine (mg)

Riboflavin (mg)

Nicotinic acid (mg)

Pantothenic acid (mg)

\begin{tabular}{|c|c|}
\hline \multicolumn{2}{|c|}{ Peasant cultivation } \\
\hline $\begin{array}{l}\text { Souna } \\
\text { (early) }\end{array}$ & $\begin{array}{l}\text { Sanio } \\
\text { (late) }\end{array}$ \\
\hline 9.45 & $8 \cdot 95$ \\
\hline $\begin{array}{l}I \cdot 48 \\
68 \cdot 2\end{array}$ & $\begin{array}{l}I \cdot 6 I \\
68 \cdot 3\end{array}$ \\
\hline $5 \cdot 2$ & 4.9 \\
\hline $9 \cdot 0$ & $9 \cdot 9$ \\
\hline $15 \cdot 1$ & $17 \cdot 45$ \\
\hline $343^{\circ} \circ$ & $350 \cdot 0$ \\
\hline 0.050 & 0.044 \\
\hline $312 \cdot 0$ & $339^{\circ} 0^{\circ}$ \\
\hline $76 \cdot 9$ & $44 \cdot 6$ \\
\hline $4^{\circ} 05$ & $7 \cdot 6$ \\
\hline 0.28 & 0.36 \\
\hline 0.15 & 0.15 \\
\hline $2 \cdot 10$ & $x \cdot 55$ \\
\hline$I \cdot 20$ & $I \cdot 00$ \\
\hline
\end{tabular}

Experimental cultivation

$\begin{array}{ccc}\begin{array}{c}P . \text { pycnos- } \\ \text { tachyum }\end{array} & \begin{array}{c}P . \text { nigri- } \\ \text { tarum }\end{array} & \begin{array}{c}P . \text { pycnos- } \\ \text { tachyum } \\ \text { nigritarum }\end{array} \\ 9.45 & 8.30 & 9.00 \\ 1.56 & \mathrm{I} .68 & 1.59 \\ 69.35 & 69.0 & 70.1 \\ 4.75 & 5.6 & 5.0 \\ 10.3 & 12.4 & 11.3 \\ 25.0 & 42.7 & 38.0 \\ 311.5 & 359.0 & 378.0 \\ 0.080 & 0.119 & 0.100 \\ 371.0 & 374.0 & 365.0 \\ 114.5 & 110.0 & 68.5 \\ 3.25 & 3.40 & 5.35 \\ 0.37 & 0.34 & 0.38 \\ 0.19 & 0.18 & 0.22 \\ 3.05 & 5.15 & 1.90 \\ 1.45 & 1.25 & 1.05\end{array}$




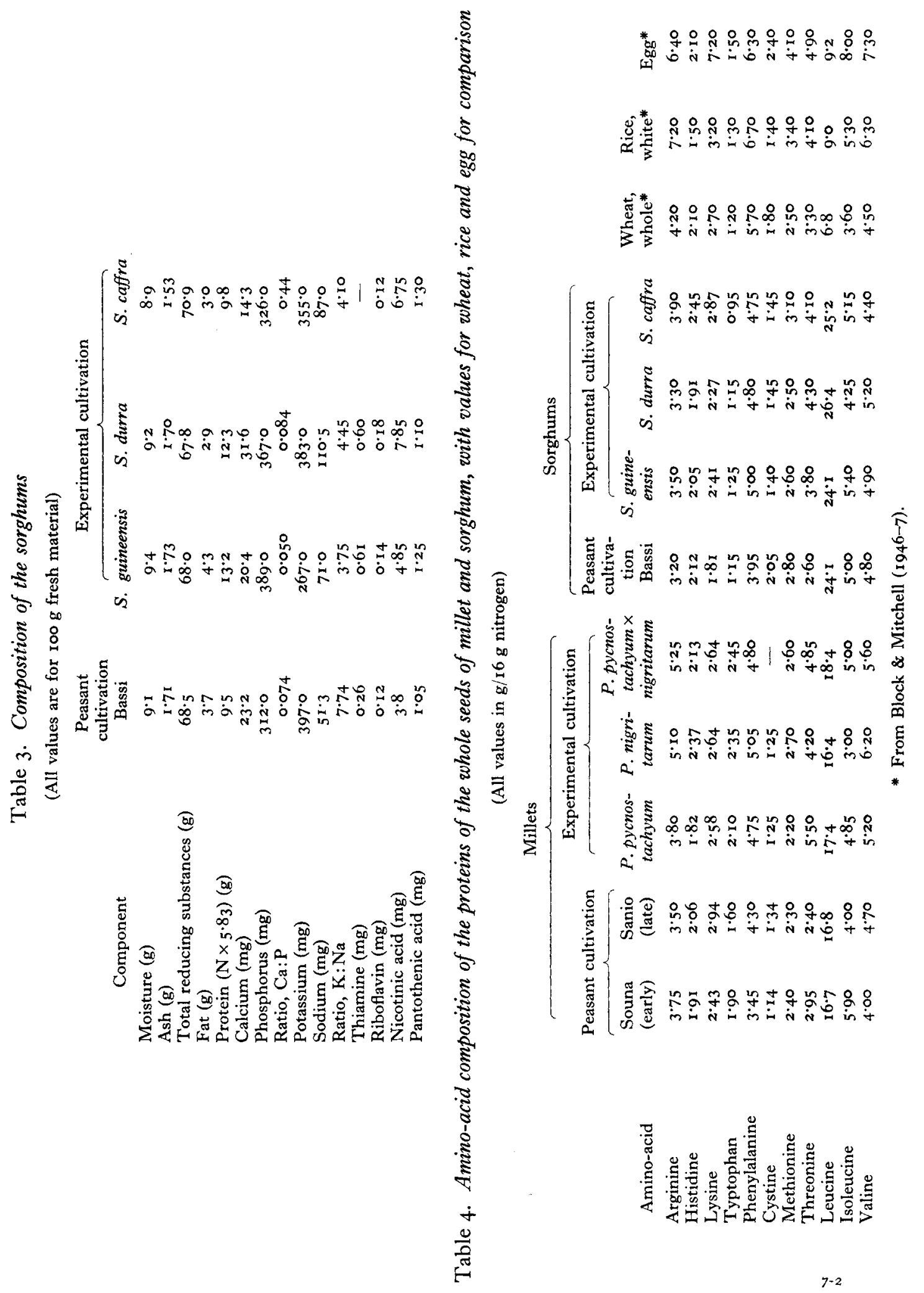




\section{Differences between the cereals cultivated by the peasants and those cultivated at the experimental station}

The products of the experimental station were with one exception considerably richer in proteins, by between $\mathrm{I}$ and $3 \mathrm{~g} / \mathrm{roO} \mathrm{g}$ seed. The beneficial action of the large quantities of manure used at the station was more marked with the sorghums than with the millets.

The samples from the station contained more of some minerals. In particular, the millets contained much more calcium, and both millets and sorghums (with the exception of the cross Pennisetum pycnostachyum $\times$ nigritarum) much more sodium.

There was no important difference in the amounts of riboflavin and pantothenic acid in the samples. On the other hand, the samples of millets and sorghums from the experimental station contained more nicotinic acid than those grown by the peasants, and the sorghums grown at the station contained more thiamine.

From results of the analysis of samples from the experimental station it appears that genetic factors play an important part in determining the composition of the grain, e.g. in the amount of protein in the sorghums, which was $13.2 \%$ in Sorghum guineensis and only $9.8 \%$ in $S$. caffra.

In general the results agree well with those of other authors who have analysed American, African and Indian millets (Balland, I902; Thebaud \& Fournier, 1947; Nicholls, 1951) and sorghums (Winton, 1902; Chamberlain, 1909; Ball \& Rothgeb, 1915; Barham, Wagoner, Campbell \& Harclerode, 1946; Thebaud \& Fournier, 1947; Fournier \& Digaud, 1948; Hubbard, Hall \& Earle, I950; Kiger, I95 I ; Nicholls, 1951).

\section{Comparison with wheat and rice}

As already indicated, millets and sorghums compete in French West Africa with wheat and rice, and it is of interest to compare their compositions. The comparison must be made on the basis of the whole grain because in this region there are such large variations in methods of milling. Wheat and rice contain half as much fat, but there is no other important difference in major constituents. The millets and sorghums contain less of the B-vitamins, and this deficiency may be of importance. Ariboflavinosis is the chief danger to cereal eaters, and next beri-beri and pellagra. The publications of Corkhill (1950), Corkhill, Creditor \& Stewart (1948) and Corkhill \& Liverp (1934) offer some confirmation on a clinical basis.

\section{Analysis of the proteins}

The proteins of millets and sorghums are remarkably similar in composition. In the proteins of the millets there are notable variations in the amount of arginine, threonine and, particularly, isoleucine. Isoleucine varied between 3 and $5 \%$ in the millets cultivated experimentally and between 4 and $5.9 \%$ in the early and late millets grown by peasant cultivation. The proteins of the three kinds of sorghum grown experimentally were almost identical in composition; it seems therefore that genetic factors do not influence the quality of sorghum proteins although they determine the amount. Perhaps the most remarkable finding was that the proteins of the millets and sorghums 
grown by the peasants were distinctly poorer in phenylalanine and threonine than those of the plants grown in the experimental station. There was about $25 \%$ more phenylalanine in the station millets and sorghums, $85 \%$ more threonine in the millets and $58 \%$ more in the sorghums. These results are important because they show that both millets and sorghums can be improved by better methods of agriculture. Balasubramanian, Ramachandran, Viswanatha $\& \operatorname{De}\left(\mathrm{I}_{95} 2 a, b\right)$ found large variations, between $4 \cdot 8$ and $7 \%$, in the amount of isoleucine in the protein of Indian sorghums. Their results showed smaller amounts of methionine and histidine but, on the other hand, larger amounts of lysine and valine than were found in our samples.

\section{Limiting amino-acids}

Table 5 shows the differences in the amounts of amino-acids in the proteins of millets and sorghums and in those of wheat, rice and egg. As with all cereals, the greatest deficit, that is the limiting factor, in the African samples is in lysine. The secondary limiting factor is cystine for the millets and sorghums and also for rice, whereas for wheat the secondary factor is isoleucine. The millets and sorghums have a great excess of leucine, and resemble maize in this respect. It is notable also that the millets have a large excess of tryptophan. Balasubramanian et al. $\left(195^{2} a, b\right)$ considered that methionine was the limiting factor in the protein of the millets and sorghums.

Table 5. Amino-acids in the proteins of millet, sorghum, wheat and rice, expressed as percentage deviations from corresponding values for whole-egg protein*

$\begin{array}{lcccc}\text { Amino-acid } & \text { Millet } & \text { Sorghum } & \text { Wheat* } & \text { Rice* } \\ \text { Arginine } & -34 & -46 & -34 & +12 \\ \text { Histidine } & +22 & +2 & 0 & -29 \\ \text { Lysine } & -63 & -68 & -62 & -54 \\ \text { Tryptophan } & +49 & -25 & -20 & -13 \\ \text { Phenylalanine } & +4 & +8 & -9 & -9 \\ \text { Cystine } & -48 & -34 & -25 & -42 \\ \text { Methionine } & -36 & -33 & -39 & -17 \\ \text { Threonine } & -18 & -24 & -33 & -16 \\ \text { Leucine } & +88 & +170 & -26 & -2 \\ \text { Isoleucine } & -43 & -35 & -55 & -34 \\ \text { Valine } & -30 & -34 & -38 & -14\end{array}$

* Block \& Mitchell (1946-7).

\section{DISCUSSION}

It is of great interest to consider the practical value of millets and sorghums in West Africa. They have smaller amounts of the B-vitamins than wheat and rice and might give rise to avitaminoses: on the other hand, however, they have more fat than wheat and rice. The ratio of calcium to phosphorus in all four cereals is very low.

The differences between the plants cultivated by the peasants and plants cultivated under the most favourable conditions in the experimental station indicate what could be done by education and the introduction of improvements such as manuring. It is uncertain, however, if the differences in composition have any physiological importance. The digestibility of the whole grain of millets and sorghums is satisfactory according 
to Adolph \& Wang (1933) and Mangold \& Stotz (1935), but the biological value of the proteins is poor: $\mathrm{Li} \mathrm{(1947)} \mathrm{and} \mathrm{Mitchell} \mathrm{(1948)} \mathrm{reported} \mathrm{values} \mathrm{of} 57$ and $5^{6}$ for the protein of millets. Animal experiments suggest that on the whole millets and sorghums have between 60 and $90 \%$ of the nutritive value of the cereals more usually eaten in European countries, and a similar range of values may perhaps be accepted for man. Exact comparisons of the nutritional status of communities using the different kinds of cereal, and properly controlled experiments in their use, are obviously needed.

\section{SUMMARY}

I. Analyses were made of two varieties of millet and one variety of sorghum cultivated by peasants and of three varieties of millet and three of sorghum grown at a research station.

2. The millets and two of the sorghums from the research station contained considerably more total protein and sodium, and the millets more calcium.

The millets and sorghums from the research station also contained more nicotinic acid and the sorghums more thiamine.

3. There were large differences in the amount of protein in different varieties of sorghum, that must have been determined genetically.

4. The proteins of millets and sorghums grown experimentally were richer in phenylalanine and threonine. On the whole, the proteins of all the millets and sorghums were similar in composition, although there were large variations in the amounts of arginine, threonine and isoleucine.

5. The limiting amino-acid of the millets and sorghums is apparently lysine, as with other cereals.

We are very grateful to M. Bouffil and M. Sauger, of the Station de Recherches Agronomiques at Bambey, Senegal, who provided us with the samples grown at the Station. We have also to thank Dr R. F. A. Dean for translating our manuscript into English, and M. M. Autret for the interest he has once more shown in our work.

\section{REFERENCES}

Adolph, W. H. \& Wang, T. C. (1933). Chin. med. F. 48, 59.

Adrian, J. (1955). Bull. Soc. Chim. biol., Paris, 37, 107.

Association of Official Agricultural Chemists (1945). Official and Tentative Methods of Analysis, 6th ed. Washington: Association of Official Agricultural Chemists.

Balasubramanian, S. C., Ramachandran, M., Viswanatha, T. \& De, S. S. (1952a). Indian F. med. Res. 40, 73 .

Balasubramanian, S. C., Ramachandran, M., Viswanatha, T. \& De, S. S. (1952b). Indian F. med. Res. 40, 219.

Ball, C. R. \& Rothgeb, B. E. (1915). Fmrs' Bull. U.S. Dep. Agric. no. 686.

Balland, A. (1902). C.R. Acad. Sci., Paris, 135, ro79.

Barham, N. H., Wagoner, J. A., Campbell, C. L \& Harclerode, E. H. (1946). Tech. Bull. Kans. agric. Exp. Sta. no. 61.

Block, R. J. \& Mitchell, H. H. (1946-7). Nutr. Abstr. Rev. 16, 249.

Chamberlain, J. S. (1909). Chem. Bull. U.S. Dep. Agric. no. 120.

Corkhill, N. L. (1950). F. trop. Med. Hyg. 53, 125.

Corkhill, N. L., Creditor, H. \& Stewart, G. E. S. (1948). F. trop. Med. Hyg. 5x, 16o.

Corkhill, N. L. \& Liverp, M. B. (1934). Lancet, 226, 1387. 
Food and Agriculture Organization of the United Nations (1953). Yearb. Fdagric. Statist. 7, pt. 1, p. 39. Fournier, P. \& Digaud, A. (1948). Bull. Soc. sci. Hyg. aliment., Paris, 36, 33.

Hubbard, J. E., Hall, H. H. \& Earle, F. R. (1950). Cereal Chem. 27, 415.

Kiger, J. (1951). La Biscuiterie, Patisserie et Boulangerie Industrielles et les Produits de Régime. Paris: Giradot.

Krehl, W. A., Strong, F. M. \& Elvehjem, C. A. (1943). Industr. engng Chem. (Anal.), r5, 471.

Li, T. W. (1947). Chin. F. Nutr. 2, r.

Mangold, E. \& Stotz, H. (1935). Arch. Geflügelk. 9, I.

Mitchell, H. H. (1948). In Proteins and Amino Acids in Nutrition, p. 46. [M. Sahyun, editor.] New York: Reinhold Publishing Corp.

Nicholls, L. (195I). Tropical Nutrition and Dietetics. London: Baillière, Tindall \& Cox.

Pennington, D., Snell E. E. \& Williams, R. J. (1940). J. biol. Chem. 135, 2 I3.

Sarett, H. P. \& Cheldelin, V. H. (1944). Y. biol. Chem. I55, I 53.

Snell, E. E. \& Strong, F. M. (1939). Industr. Engng Chem. (Anal.), II, 346.

Thebaud, A. \& Fournier, P. (1947). Rapport no. 3 de la Mission Anthropologique, Service de Santé. Dakar: Gouvernement général de l'A.O.F.

Viguier, P. (1947). Les Sorghos et leur Culture au Soudan Français. Dakar: Gouvernement Général de l'A.O.F,

Winton, A. L. (1902). Bull. Conn. agric. Exp. Sta. no. 326.

\title{
Serum electrolytes and proteins in kwashiorkor
}

\author{
By W. M. POLITZER AND S. WAYBURNE \\ South African Institute for Medical Research and Baragwanath Hospital, \\ Fohannesburg
}

(Received 5 fune 1956-Revised I8 September 1956)

The purpose of this investigation was to study the pattern of serum sodium and potassium in kwashiorkor and to ascertain whether it can be related to the presence or absence of oedema or diarrhoea, whether it alters with the rise of serum protein levels in response to a high-protein diet, and whether abnormalities in the electrolyte pattern are responsible for the deaths which sometimes occur in children suffering from this disorder.

\section{EXPERIMENTAL}

Subjects. Investigations were carried out on sixty-three children, sixty Africans and three of mixed race, who were admitted to the Paediatric Department of Baragwanath Hospital. All were suffering from severe kwashiorkor, the diagnostic criteria being irritability, dermatosis, oedema, discoloration and change in the texture of the hair, and low weight for age, all of which were present in most of the subjects. Their ages varied from 8 months to 6 years, the mean age being 20 months. There were thirty-seven males and twenty-six females. On admission all but four of the patients had marked oedema, which added to their initial weight. Weight for age is shown in Fig. I, in comparison with average weights of normal controls.

Patients with renal or cardiac oedema, and those known to be suffering from tuberculosis, dysentery or parasitic infestations were excluded from this study. 